\title{
Development Model of Rice Supply Chain Management to Ensure Self-Sufficiency and Food Security
}

Submitted Date :

3 September 2021

Accepted Date :

22 November 2021
Yuntawati Fristin*

Universitas Merdeka Malang

yuntawati.fristin@unmer.ac.id

Fajar Supanto

Universitas Merdeka Malang

fajar.supanto@unmer.ac.id

\section{Suggested Citation:}

Bala, B. K., Bhuiyan, M. G. K., Alam, M. M., Arshad, F. M., Sidique, S. F., \& Alias, E. F. (2016). Modelling of supply chain of rice in Bangladesh. International Journal of System Science: Operations \& Logistics, 2674(May)

Abstract:

The purpose of this study to investigate the formulation of effective and efficient measures to increase the rice distribution chain linkages in Malang Regency. The study design is a combination of descriptive and policy research unit by applying analysis of Rice Milling Unit (RMU) Entrepreneurs, Wholesalers and Retailers, Farmers and stakeholders concerned. The sampling was carried out by non-probability sampling method. The first sampling used purposive sampling method, and then the snowball sampling method. The data processing was done by the framework of the Food Supply Chain Networking (FSCN). The results indicated that Malang Regency has successfully contributed to the increase of national unhulled rice production. Furthermore, every year Malang Regency has a surplus of rice. The rice distribution pattern consists of the rice traders, millers, wholesalers, Bulog Malang Sub Division, and retailers. The results of this study provide interesting findings because the rice produced by farmers in Malang Regency is mostly sold outside Malang Regency. To Strengthen the supply chain management of rice, it is needed the growth and strengthening of the system either upstream or downstream of economy through institution of the village. The institution has a bridging function for both the interests and needs of the community. The government should provide sufficient funds through Bulog to buy all rice produced by farmers at a price that supports farmers in making a profit, then distribute it to the community at a price affordable to the purchasing power.

Keywords: Distribution Patterns; Food Supply Chain Networking; Resilience and Self-Sufficiency; Supply Chain Management JEL Classification: D39; 013

*Corresponding Author 


\section{Introduction}

Food security has become a very important issue for almost every country in the world, including Indonesia. Indonesian society has indeed been known to consume rice as the staple food. Rice is the main food for more than $95 \%$ of Indonesia's population. In addition to producing rice as the main product, rice farming creates jobs and income for around 21 million farm households in rural areas (Sudaryanto, 2013). When the demand of rice is larger than the supply, then emerge problems that could threaten national food security. Disturbances in food security (rice) such as the lacking of the rice availability and rice price increase can trigger social insecurity, economic and political instability and overall can disrupt the national stability (Firdaus et al., 2008).

In assuring food security, a good supply chain management of rice is needed. At present, agro-industrial supply chains are becoming more coordinated and competitive amid trade liberalization, globalization and the emergence of challenges related to its development (Timsina et al., 2016; Yan et al., 2017). A good organization and arrangements of supply chain of rice may support the success of this program. Supply Chain Management (SCM) becomes important to be applied to ensure the sustainability of agro-industry so that in the end it can contribute to the national food security. Through the SCM, it is expected that supply of raw materials, semi-finished and finished materials in this agro-industry can be assured, so that the continuity of production can take place and consumers' demands can be met.

The application of SCM in the supply chain of various products may have different strategies in order to meet the demands and satisfaction of the customers. In general, every SCM aims to maximize profits/surplus of the overall supply chain. The greater the benefits earned by the parties involved in a supply chain as a whole, the more successful the supply chain is. The supply chain not only supports sectors that are directly involved, supply chains also provide social, economic and environmental development in a region or country (Harrison \& Hoek, 2008).

Several studies related to the rice supply chain have also been carried out. Sathapatyanon et al. (2018) outline the role of networks and cooperatives in the rice supply chain. Nee (2008) and Obura et al., (2017) explain the obstacles that arise in the rice supply chain. Aji (2012) examines how the rice supply chain works. Sharma et al., (2013) reviews the rice supply chain from the perspective of a rice processing company. Guritno et al., (2018) tried to map the risks that arise in each of the actors in the rice supply chain. Bala et al., (2016) developed a causal loop model to see the stability of the rice supply chain.

In term of the root of the problems faced in efforts to increase the added value of the rice supply chain is very diverse with different levels of difficulty such as: 1) failure to operate because they do not get certainty about the supply of inputs and marketing of outputs; 2) Financial institutions do not see the perspective of the chain of production, processing, marketing as a series of businesses that operate in unison and can provide a guaranteed return of capital and 3) The involvement of input, process, output and market access is often not organized properly.

Therefore, it is expected that the implementation of SCM can increase the income of farmers in particular, and also increase the income of stakeholders throughout the supply chain. Besides, by applying proper SCM for crops, it is expected that the involved parties will grow and operate sustainably. Thus, it is necessary to carry out a study and analysis on the existing supply chain today as an input for designing a model of supply chain management of rice in order to increase self-sufficiency and food security in Malang regency based on the present findings in the target area, so that strategic policies issued by the local government can be effective and efficient. The main purpose of this study was to develop a model of rice supply chain management (RSCM) to improve self-sufficiency and food security in Malang Regency and then based on the model it will be designed a program for the implementation and evaluation of the Model.

SCM was first proposed by Oliver \& Webber (1982). SCM is a set of approaches that are applied as an attempt to integrate suppliers, entrepreneurs, warehouses and other storage areas efficiently so that products can be produced and distributed with the right quantity, right location and the right time in order to satisfy the needs of consumers (Simchi-Levi et al., 2008). Supply chain management is a strategic and systematic coordination among companies in supplying of raw materials, producing goods, and sending it to the final consumers (Anatan \& Ellitan, 2008). Chopra \& Meindl (2004) state that the supply chain management includes management on flows among tiers in a supply chain to maximize the total profits. Supply chain management is a concept that is increasingly important in the era of free trade and globalization. In supply chain management, there are four drivers. They are supplies, 
transportation, facilities, and information. Among those four drivers, information becomes the main driver. Information greatly affects the three other drivers.

According to Chopra \& Meindl (2004), the business process in the chain can be seen from two views: cycle view and push or pull view. Cycle view explains that there are several cycles in which each cycle occurs between two members of the supply chain dealing. Push or pull view explains that there are two categories of view depending on the actions of members of the supply chain in response to consumer demands or as an action of anticipation for consumer demands. The pull process is a process of responding to consumer demands, while the push process is a process carried out by the members of the supply chain as anticipation of consumer demands.

There are several dimensions in the coverage area of supply chain management that must be maintained, managed, and integrated. Those dimensions are (Anatan \& Ellitan, 2008): 1) Dimension of movement of goods, including packaging customization, common containers, and vendor management inventory; 2) Dimension of planning and control, including joint activity or planning and multilevel supply control; 3) Dimension of organization, including partnership, quasi firm, virtual firm, and just in time; 4) Dimensions of information movement, including production plan sharing, Electronic Data Interchange, and the internet.

SCM is different from the supply chain. Supply chain is a network of physical or container companies involved in supplying raw materials, producing goods, and sending it to the final consumers, while SCM is a concept, idea, method, tool or approach of SCM. It should be emphasized that SCM is an integrated approach from the upstream to downstream as it has $3 \mathrm{C}$ principles: Coordination, Collaboration, and Cooperation among all members of a supply chain (Oliver \& Webber, 1982; Lambert et al., 1998)

In the SCM there are six key basic principles for the development of an optimal supply chain. Those six principles are (Collins et al., 2002): 1) Focus on consumers and customers As the growing number of competing businesses, supply chain management turns into a pull system, in which consumers act as the determinants of decisions made by a company (Anatan \& Ellitan, 2008). Understanding consumer needs and how suppliers work is something that is very fundamental and important in the supply chain because the ultimate goal of supply chain management is the satisfaction of the final consumers who demand better, cheaper products, and faster, 2) Creating and spreading values: Value creation is fundamental to customer satisfaction. In regulating a supply chain, the distribution of the values of each member involved should match the measurement of each value created or added by each member. That value will be created if each member can innovate and use technology that can make production efficient and effective; 3) Implementing an effective quality system management: Quality is no longer only within specification, but everything outside the price desired by the customers, such as the time of delivery, constraints of promise, form or aesthetics and durability of the products, products' safety, after-sales service, and so on; 4) Developing open communication systems: Accurate and reliable information is the main foundation in creating effective communication. Open communication is the stepping stone of a good relationship among the existing members. Communication can also be used as a reference in creating added value; 5) Guaranteeing or ensuring effective and efficient logistics system: Logistics management includes the handling, storing, and shipping. Supply chain management is a development concept of logistics management in which their applications are different between the two. Supply chain management concerns about the logistics distribution from suppliers to the final consumers in the supply chain, whereas logistics management only pays attention to the logistics conditions in the company of every member of the supply chain (internal); 6) Building good relationships with members of the supply chain: A good marketing relationship is very necessary to succeed the cooperation within a supply chain. Each member in the supply chain should be open and honest on the information contained therein. This is done so that the information they obtain causes no misunderstanding or miscommunication so that the connections between them will be maintained.

Designing and implementing optimal supply chain globally is quite difficult owing to its dynamics as well as conflicts of interest between the facilities and the partner (Simchi-Levi et al., 2008). Studies and research in developing and optimizing SCM for agricultural products (agro-industry) are majority done in line with the research done in the realm of SCM for manufactured products. Agro-industrial products include products from companies that 
process materials originated from plants and animals. The processing includes the transformation and preservation through physical or chemical changes, storage, packaging and distribution (Brown, 1994).

The term agro-industry supply chain (agri-food supply chain) itself is used to describe activities from production to the distribution process that brings horticultural or agricultural products from farms to the consumers (Ahumada \& Villalobos, 2009; Shukla \& Jharkharia, 2013; Dinu, 2016). Agro-industry supply chain formed by a series of organizations that carry out the production process (by farmers), the distribution process, the process of processing and marketing of agricultural products to consumers.

Clear differences in the characteristics between manufactured products and agro-industrial products also make a difference in their supply chain. According to Aramyan et al., (2006), the things that make agro-industry supply chain different from the supply chain of other products are: 1) Nature of the production, which is partly based on biological processes, thereby increasing the diversity and risk; 2) Nature of the product, which has some special characteristics, such as perishable and bulky, so it requires specific types of supply chain; and 3) Social and consumers' behavior towards the issues of food safety, animal safety, and environmental stress.

The purpose of a supply chain is to maximize the overall value generated, which represents the difference between the value of a final product for consumers with supply chain costs incurred in meeting the consumer demand. For almost all of the supply chains, value is highly correlated with the profit of the supply chain (supply chain profitability / supply chain surplus), which is the difference between the income earned from consumers and the overall supply chain costs.

The advantage of the supply chain is total profits divided at all stages of the supply chain. The higher the profit in a supply chain, the more successful the supply chain is. The success of a supply chain should be measured in terms of the benefits of a supply chain as a whole and not of the profits of each party. For any supply chains, there is one source of income, the consumers. Meanwhile the entire flow of information, products and funds produce (cost) for the supply chain. Therefore, a good management of the flow is the key to the success of the supply chain. Effective supply chain management involves asset management of products, information, and the flow of funds to maximize the benefits for the supply chain (Chopra \& Meindl, 2004).

\section{Research Method}

The research design is a combination of descriptive and policy research in order to develop the rice supply chain management model that is effective and efficient in Malang Regency. Unit of analysis are: 1) the RMU entrepreneurs, wholesalers and retail; 2) farmers and; 3 ) the relevant stakeholders. The first sampling of the rice supply chain analysis was done by purposive sampling method, farmers. And then, the next sample is determined by susing snowball sampling method in which samples were obtained based on information from previous the respondents by following the flow of rice supply from suppliers to the final consumers. The data collection technique used in this study were questionnaire, interview, and FGD. The rice supply chain model was analyzed using the supply chain development which follows the framework of Food Supply Chain Networking (FSCN) of Lambert and Cooper, later modified by Van Der Vorst (2006).

Result

Most of the area in Malang Regency is agricultural land including 14.31 percent (45.888 hectares) paddy's field, 32.06 per cent (102.819 hectares) tegal / garden / farm, 7 percent (22.443 hectares) plantation areas, and 13.65 percent (43.782 hectares) forest. The leading sectors in Malang Regency were the industrial sector, agriculture, and construction sector. Based on data of contribution of each sector to the GDP it indicated that around 29.59 percent of the GDP was contributed by the industrial sector. Furthermore, the second largest contributor to the GDP was agriculture and forestry as much as 17,55 percent of the GDP. The third largest contributor to the GDP was the construction sector as much as 12.03 percent.

Food production, especially rice in 2015 reached 478.930 tons. The increase in rice production is supported by several buffer zones, even among them rose rapidly in the Dampit District, Bantur, Kepanjen and Singosari while other contributing buffer zones were Donomulyo, Pagelaran, Sumberpucung and Pakis District. Among 45888 hectares of wetland, Gondanglegi District has the widest agriculture area of 2,969 hectares and the least is Ampelgading with an area of 407 hectares. Nevertheless, the biggest rice producer is Dampit District which produces 41.928 tons of rice and the smallest is Pujon with the production of 2.663 tons. 
Every year, Malang Regency experiences an average surplus of 60 thousand tons. Furthermore, in the year 2014 Malang Regency experienced a surplus of 50838 tons. The productivity of average harvest reached 7.05 tons per hectare. The yield of farmers' milled rice (paddy)'s average reaches 62 percent and the lowest is 60 percent. Meanwhile, yield produced by farmers in Kepanjen is the highest, between 69 to 70 percent. Therefore, the middlemen or distributors prefer buying rice crop from farmers in Kepanjen because the yield is high.

The results achieved in the past 5 years has made Malang Regency the granary of East Java Province and made a major contribution as a source of supply of rice in East Java Bulog (tons). This is shown by the data of procurement of rice originating from Malang Regency which occupied the 7th place out of 12 cities.

Rice is the most strategic commodity and contains a political element, the balance of availability and needs indicates a significant surplus. This indicates that Malang Regency is self-sufficient in rice so that the needs the population will be met from existing rice supply. Although the balance sheet indicates a surplus, this condition still needs a serious attention because domestic demand is likely to increase in tandem with the growth of availability so that domestic production capacity may not meet the demand.

The demand for rice in Malang Regency is quite large. According to the data obtained from the Department of Agriculture \& Gardening, the needs of rice approximately reach $92.27 \mathrm{~kg} /$ capita / year, assuming that rice production is $62.77 \%$ percent of the yielded unhulled rice, the surplus of rice in Malang Regency reached 68717 tons.

Figure 1. Map of Food Security Malang Regency

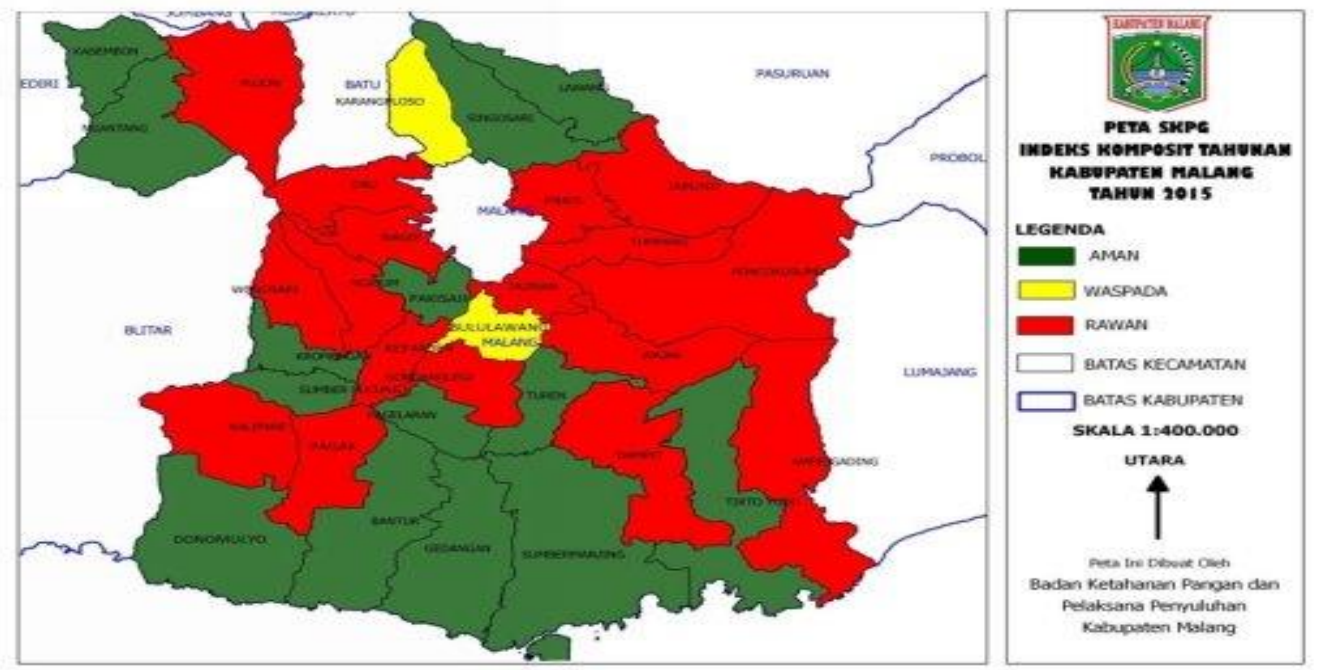

Source: BKP3 of Malang Regency (2015)

\section{Discussion}

\section{Rice Distribution Pattern}

Unhulled rice/rice distribution pattern in Malang Regency consists of five main stakeholders as follows: 1).Villagelevel traders (local traders) acts by buying unhulled rice from farmers in the form of GKP then proceed the purchase to the rice milling unit (RMU).Village-level traders may also act as middlemen; 2). Rice Milling Units (RMU) accommodate the results of local trades. The collected unhulled rice is then dried into milled unhulled rice (GKG), or the RMU can also buy unhulled rice directly from farmers. These grains are then milled into rice or sold back to the sub division of BULOG or to wholesalers; 3). Sub Division of Bulog accommodates unhulled rice and rice from RMU and BULOG's business partners or wholesalers and may also sell rice to the central market in the district level (wholesale) as well as to retailers; 4). Wholesalers accommodate unhulled rice from the RMU or local traders then supply it to the local sub BULOG in the form of milled dried grain or they can also sell rice to the central market in the district level (wholesale) as well as to retailers. 
In Malang Regency, no less than five large-scale rice traders are active in rice marketing. Those rice traders generally have an RMU and drying floors. In addition to supplying rice to the wholesalers in the district or interdistrict, these large-scale traders sometimes also supply the rice to the provincial level wholesalers. The results indicate that the source of rice supply in circulation in Malang Regency generally does not only come from Malang, but also from various regencies in East Java, even from Central Java and West Nusa Tenggara.

Figure 2. Rice Supply in Malang Regency

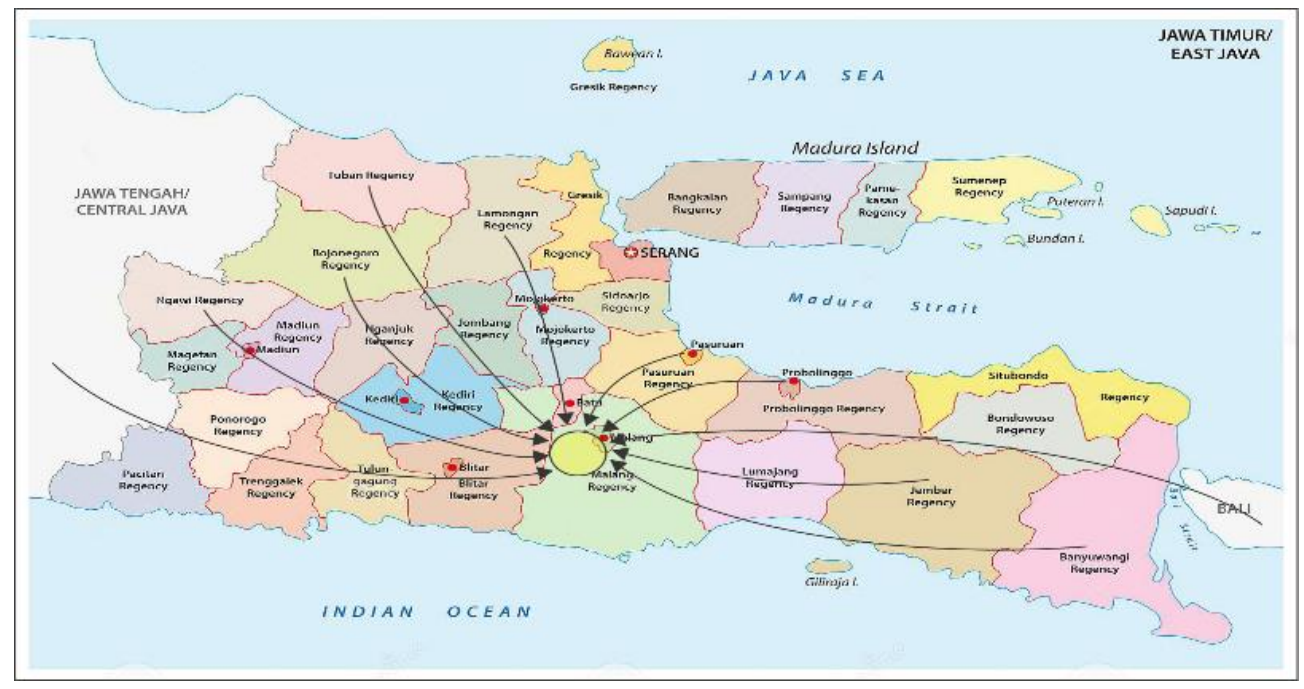

Source : Data Processed (2015)

This finding is very interesting because the rice produced by farmers in Malang Regency is actually sold outside Malang Regency. Most of the people in Malang Regency consume rice from other regions because the price is cheaper than the rice produced by Malang Regency farmers. This condition should increase the welfare of farmers because the rice produced is of premium quality and is more expensive. The market mechanism makes this expectation difficult to fulfill because the price is completely dependent on RMU.

\section{Rice Supply Chain Structure}

Most of the rice supply chain models in Indonesia are still traditional. Traditionally practiced supply chains are less efficient for several reasons, namely the large number of intermediaries between farmers and rice processing companies, and between processors and customers, resulting in greater complexity, lower efficiency, and increased costs of the product (Sharma et al., 2013).(Lin \& Wu, 2011)

In Malang Regency, the structure of the rice supply chain can be analyzed through the members that make up the supply chain and the role of each member as well as entities or elements contained in the supply chain such as products, markets, stakeholders, and the competitive situation. The supply chain members are actors engaged in the product flow, financial flow, and information flow. Final consumers become a part of the structure of the supply chain for the final consumers are also involved in the product, financial, and information flow. The structure of the supply chain of Bulog is in the form of network, or better known as supply chain network.

Figure 3. Rice Supply Chain Structure 

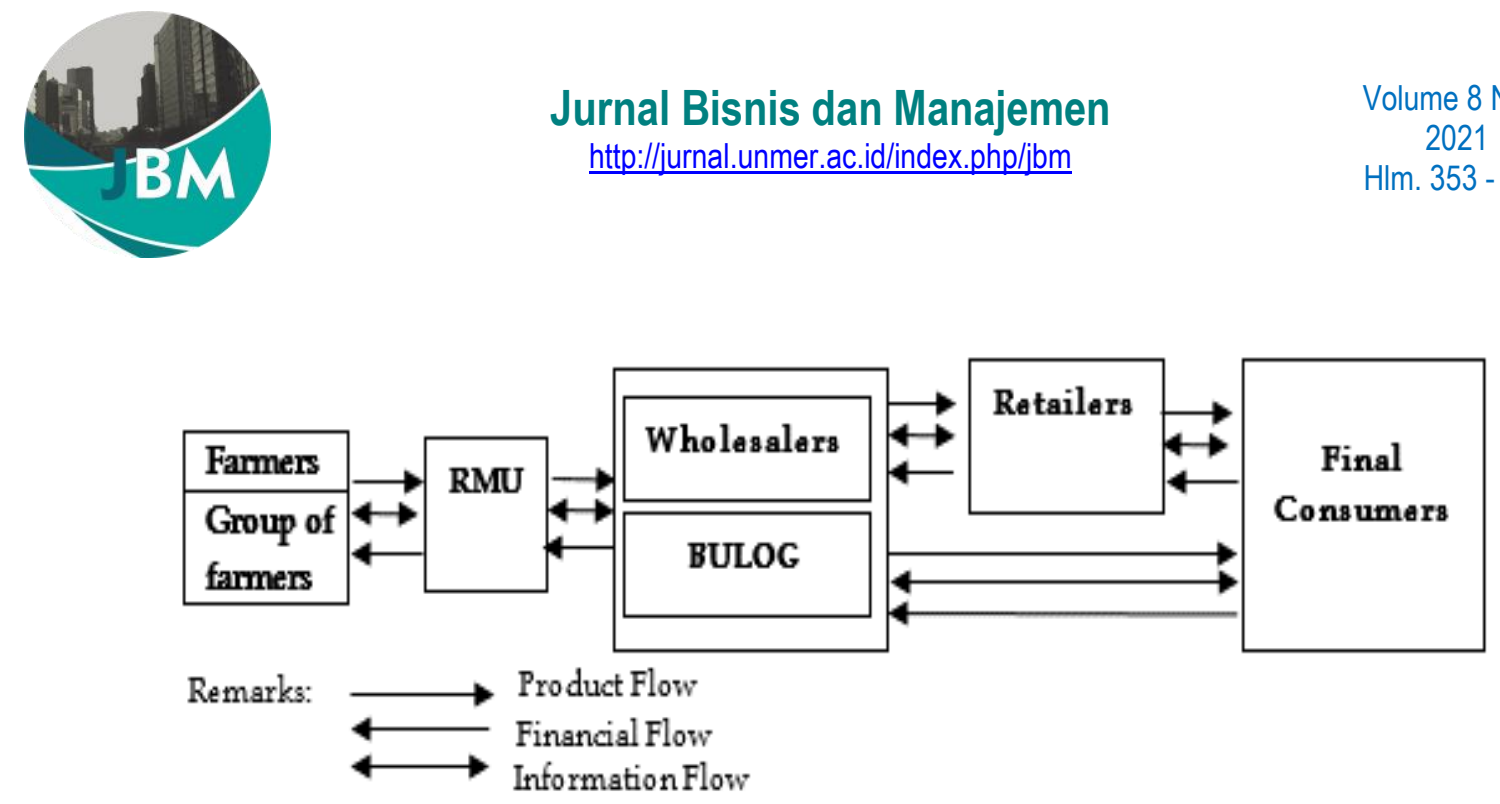

Source : Data Processed (2015)

Chain structure as shown in the Figure is the structure of the supply chain network in which each member of the supply chain has been grouped on the basis of roles similarity. Farmers are grouped as partner farmers and retailers that distribute the rice are classified as product retailers. Farmers / Group of Farmers described as every respondent farmer averagely has around one to three women workers. Men jobs are usually done the farmers themselves and they help each other. During the cultivation of rice, women workers are in charge of sowing, planting rice seedlings, pulling weeds, and removing the grains manually. Meanwhile, farmers cultivate the land using tractors, spray liquid fertilizer and PGR (plant growth regulator), set up irrigation, and harvest the rice, Rice farming for local farmers is already commercial for the main goal is to make a profit and it has become their main job. Rice variety used is mostly IR-64. After harvest, farmers remove the unhulled rice and dry them in the courtyard area by using sunlight. Removing the grains is done manually. And then, the dried grains are shipped directly or by traders to the RMU for milling. Milling of grains is carried out by itinerant RMU or RMU stationary. Simultaneously, Gatherer Traders in this study identified by Rice grain buyers are generally village-level grain traders. These traders are partners of the local RMU, the method of payment is in cash, and the price is determined through bargaining agreements. Generally, unhulled rice traders or village-level traders are partners of rice milling unit (RMU). Every rice production center village has at least a stationary unit of RMU. To assure the continuity of obtaining grains, each unit of RMU has 10 15 unhulled rice collectors. These unhulled rice traders obtain a working capital from an RMU, with a condition that their purchased grain has to be milled in the RMU. Finally, Rice Milling Unit (RMU) were Village-level grain traders and RMU are members of the chain after the farmers. Both also play an important role in the rice supply chain, that is, as an intermediary between the farmers and the Bulog and Wholesalers as well as the intermediaries between the farmers and the final consumers.

RMU conducts shipping, sorting, packaging, labeling, and marketing to wholesalers, Bulog, retailers and the final consumers. The grain the farmers harvest is transported to the drying floors. The dried grain is then sacked and shipped to the mill. Sorting is done after the milling process, which is to separate the rice grains and the groats (broken rice) then the rice grains are packed with plastic packaging size $5 \mathrm{~kg}, 10 \mathrm{~kg}, 25 \mathrm{~kg}$ and $50 \mathrm{~kg}$ with a label on the packaging while the groats are sacked size $50 \mathrm{~kg}$ without a label. The label is attached to the plastic packaging. Packaging using plastic is done 0$\}$ the rice arrives at the warehouse after being transported from the mill. The shipping of rice that has been packaged to retailers is done using a pickup car. Arriving at the retails, the rice packaging and labeling may be replaced with new packaging and labels. RMU also sells rice directly to the final consumers. The rice market shares of the RMU are neighbors and residents who live nearby, family and the owners' partners. Total sale is all the rest of the supply of rice deducted from sales to wholesalers. The rice sold to the RMU is premium, medium and low-grade rice with a variety of price levels.

Milling entrepreneurs who become the rice supply chain actors are generally those who are able to produce 45 tons of unhulled rice per day. RMU are generally partnered with village-level traders, the method of payment is in cash, and the price is determined through bargaining agreements. The activities done in rice mill unit (RMU) are collecting rice from local traders and improving the quality of rice produced sale value can be boosted. 
Competition among RMUs is also very strict in obtaining raw materials in the form of unhulled rice in order to enlarge the business' quantity and volume. Sometimes when there is a shortage of unhulled rice in the area of operations, the RMU imports it even from outside the district such as Bojonegoro, Tuban, Lamongan, Jember, Banyuwangi, Probolinggo or neighboring provinces such as Central Java, especially Sragen.

Wholesalers members of the chain after RMU. These business entities also play an important role in the rice supply chain, that is as an intermediary between the RMU, Bulog, retailers, and final consumers. Wholesalers perform activities of shipping, sorting, packaging, labeling, marketing to Bulog, retailers, and final consumers. The role of wholesalers is the same as RMU' role; buying unhulled rice as well as rice. The market sales of rice of wholesalers cover a wider area even outside of the city. Like RMU, wholesalers and Bulog also sell rice at various grades and prices, beginning from premium, medium, low, and very low.

Besides the purchase of unhulled rice done by traders who are the representative of RMU, the purchase is also done by Bulog in partnership with RMU and gapoktan (group of farmers). Bulog is a state-owned enterprise engaging in the food logistics. The company business scope includes logistics/ warehousing business, survey and pet eradication, supply of plastic bags, transportation business, food commodity trading and retail businesses. As a state-owned enterprise, BULOG keeps maintaining the basic price for unhulled rice, price stabilization especially basic price, distributing rice for poor people and management of food stocks. To secure the price of unhulled rice at farmer level, the Food Security Agency of Malang Regency obtains the fund for unhulled rice procurement and other foodstuffs from the Regional Government Budget. The mechanism of unhulled rice and other foodstuffs procurements are closely supervised by the Food Security Agency is supervised by the technical team. The lack of direct access from farmers to Bulog causes the rice produced to be sold to RMU so that prices are very dependent on market mechanisms. Indonesia needs to learn from Thailand in rice management. All rice produced by farmers in Thailand is purchased by the Government at a price that supports farmers in making a profit, then distributed to the people at a price affordable to the purchasing power of the Thai people (Saragih, 2016).

\section{Rice Supply Chain Management Model}

Effective Supply Chain Management will make the organization gain several advantages, such as: increasing profits, reducing costs, and / or reducing the delivery time. To achieve this, the rice supply chain management should be directed towards increasing the involvement of all members of the supply chain of rice and the related stakeholders sustainably. In the absence of such sustainability, the impact on improving added value for the supply chain members would be just a little. The roots of the problems faced in efforts to increase the added value of the supply chain of rice are so diverse with different levels of difficulty, such as: 1) failed to operate because stakeholders do not get assurances on the input availability and output marketing; 2) Financial institutions lack the perspective of the supply chain's production, processing, and marketing as a set of integrated business operations and can provide a capital guarantee, and 3) involvement of input, process, output and market access is often not organized properly.

The diversity of those problems would require a serious treatment. Therefore, the efforts of increasing the added value of the rice supply chain needs to involve all components which are divided into three series: 1) system production facilities assurance system; 2) production process assurance system, and 3) product marketing assurance system (Figure 4).

\section{Production Facilities Assurance System}

Production facilities assurance system is designed to ensure the availability of production infrastructure in an effort that the rice supply pattern will be "on the right amount, location, time, quality and price". Therefore, the availability of breeding centers, agricultural associations, agricultural machinery and tools associations, and providers of fertilizer are needed as a means of agricultural production.

Figure 4. Rice Supply Chain Management Model in Malang Regency to Increase Self-Sufficiency and Food Security 


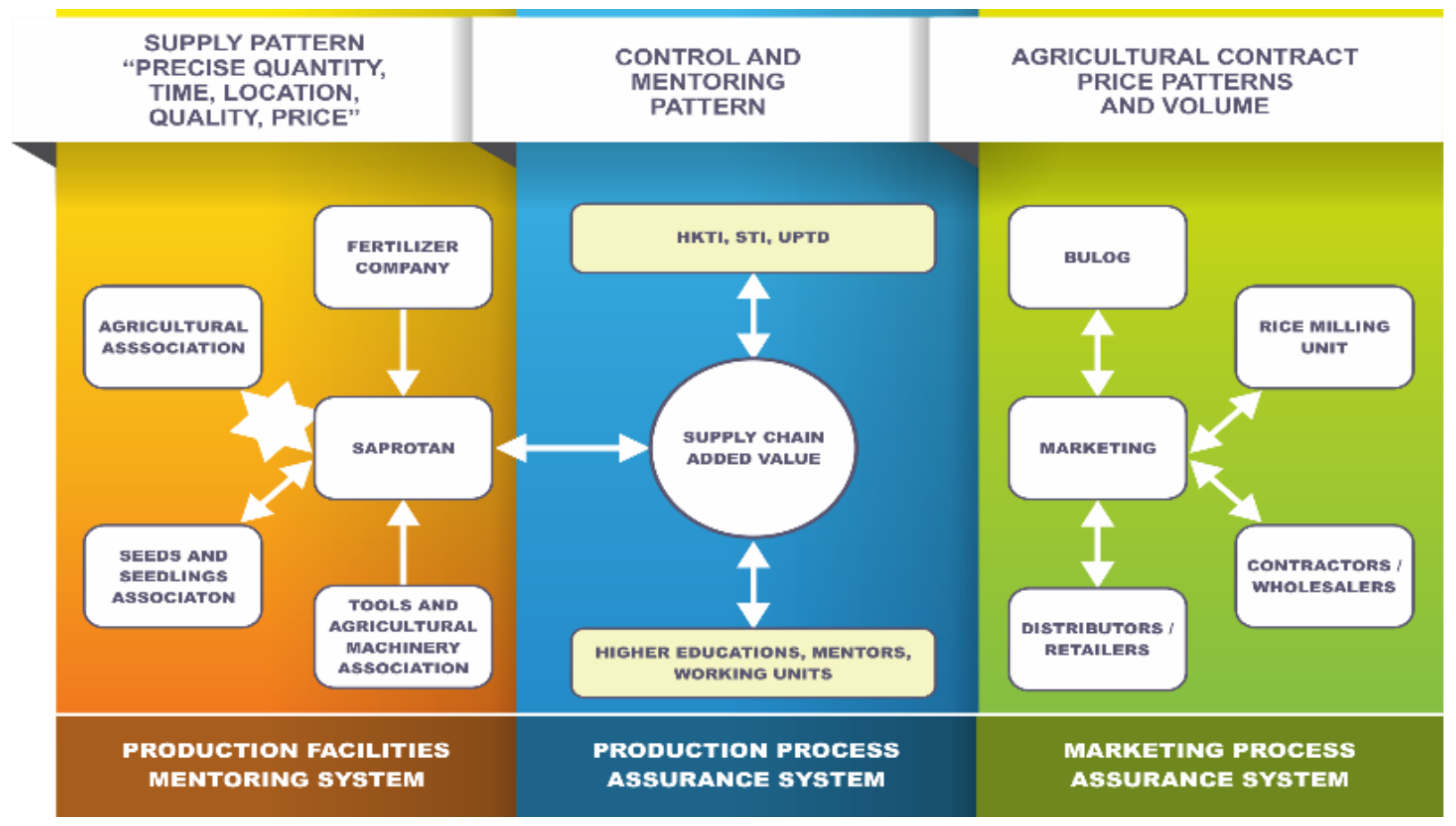

Source : Data Processed (2015)

\section{Production Process Assurance System}

The production process assurance system is intended to ensure the production process runs smoothly. Therefore, assisting and controlling the production process has to be conducted. This activity involves many interrelated parties that lead to the development of food plant agricultural sector and are able to increase the added value in the supply chain. The facts indicate that people need support in the form of assistance in which it acts as a facilitator, catalyst, development and provide other technical guidance. Creating competent and independent farmers needs the participation of various parties who have to work in synergy and coordinately in accordance with their capacity and capability. Coordination and synergy become key factors, especially for the government, because so far coordination is easy to say but hard to do. Therefore, the role of coordination becomes important in the effort to embrace all parties in realizing the optimal supply chain.

The interrelationship among parties in ensuring the production process in order to develop the ability of farmers involves existing institutions, competent resources in mentoring activities as well as using effective ways in the mentoring such as lectures, discussions, visitations, demonstration of tips or effective methods, demonstration of the method's results, counseling and participatory monitoring and evaluation. Those attempts were conducted in order to: a) increase the farmers' mastery regarding their roles (the main perpetrators of the agricultural sector), b) increase the mastery of skills especially science and technology and access to information for business development, c) increase the mastery of the resource that is the control of capital, access to the production facilities and mastery of agricultural machinery and tools. Through these efforts, it is expected to: a) increase the co-operation among farmers or farmer groups; b) to improve the farmers or farmer groups more efficient and dynamic; c) increase the farmers' ability in applying new technologies, and d) increase productivity.

\section{Marketing Process Assurance System}


The marketing process Insurance system aims at guaranteeing products from the production until the final consumers in accordance with the desired price and quantity. The active involvement and cooperation of members of rice distribution chain are needed to ensure the smooth marketing of products.

\section{Strategy and Development Patterns of Rice Supply Chain}

To strengthen the rice supply chain, the development and reinforcement of system are required. So far, the existing system has not established strongly, but focused more on the interests of the subsystem. The interwoven between the upstream and downstream subsystems have not been constructed well. Making connections between subsystems upstream, downstream and support will make the existing system solid it will strengthen the supply chain as well as expand the scope of business operation like product processing, financial institutions and marketing.

The development of downstream subsystems such as marketing agencies in business development is expected to generate relevant technical, economic and social innovation. Innovations have to be farmer-need oriented. Institutional strengthening in the development effort should be directed at developing diverse economic system. The linkage between the institutional components is needed to support the entire economic activities of farmers.

Figure 5. Strategy and Rice Supply Chain Development Patterns

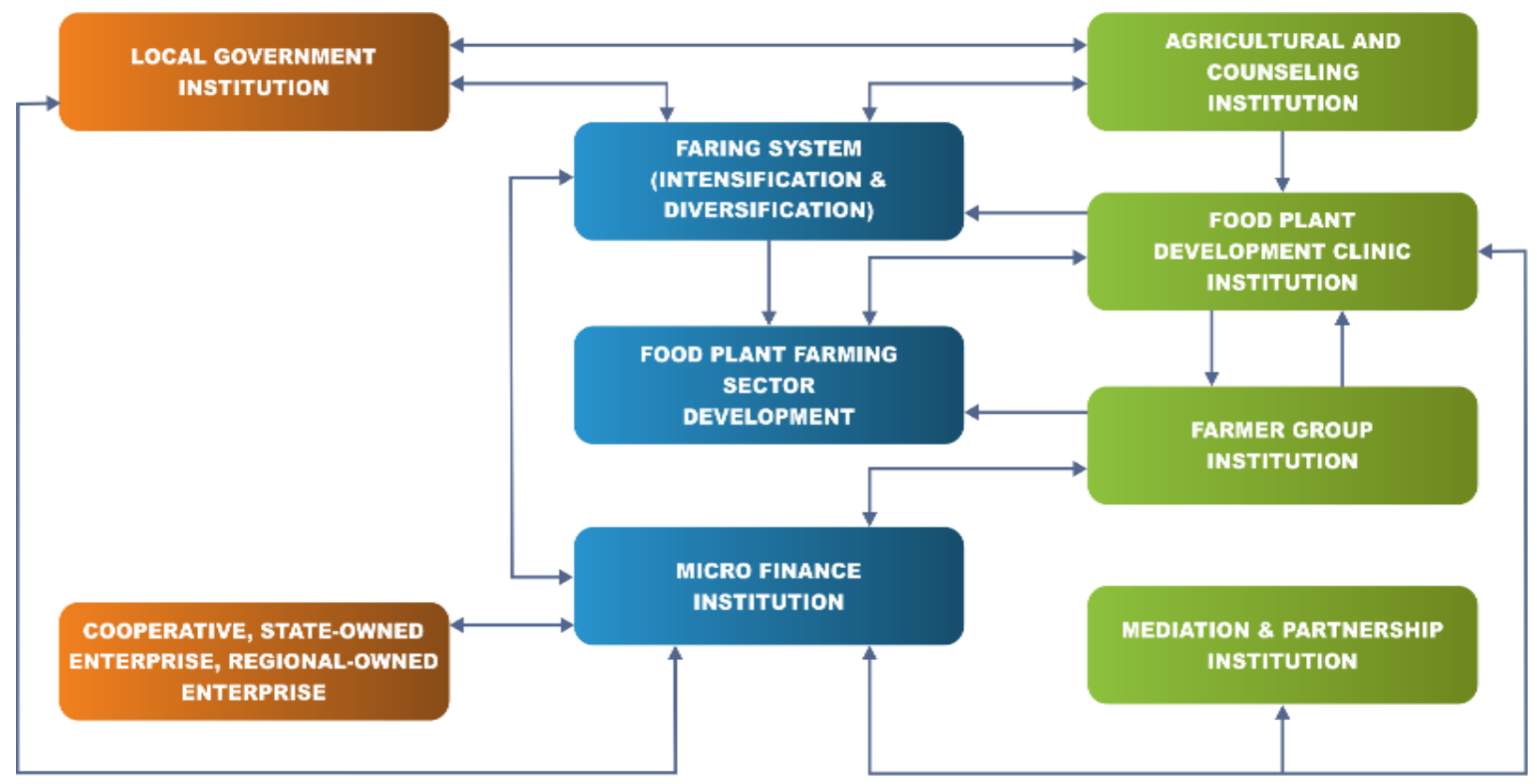

Source : Data Processed (2015)

Growing institutional element of the economic system needed is the development of the upstreamdownstream business units in the village such as provision of facilities for production business unit, rural financial institutions and farmers' product marketing unit. Development and improvement of institutional capacity is carried out in phases starting from the pilot phase and stabilization phase and development phase along with innovation and technology system phase. Phases of growth until developmental phase will be facilitated, mediated and supervised by the government institution through the district technical team conducted thoroughly by mentors.

The developed business units are directed to the stabilization of the integrated system. The linkage among the subsystems form a marketing network and a solid and sustainable partnership in stabilizing the farmers' economic activities. This network is supported by institutions outside the village community such as banking, production input providers, businesses and governments.

The government's role is to prepare policies on business development, access development to local markets, domestically and globally. Further, the expected government's roles are: 1) Creating local, domestic and global market opportunities in response to the existing development, 2) Doing breakthroughs in production systems, processing and marketing technological development, 3) Strengthening and activating relationships on a partnership 


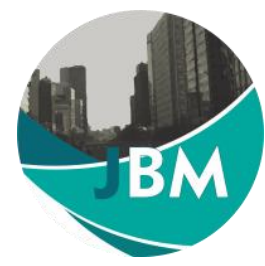

basis among the actors in the process of production, processing and marketing, 4) Identifying potential resources more intensively, 5) Creating products that have comparative advantages.

Productive economic business activities must be supported by the upstream and downstream sub-system activities and other supporting organizations' activities. One of the economic institutions to support those activities is Village-Owned Enterprise (BUMDes), a village-owned economic institution in the form of a corporation. The presence of BUMDes or cooperatives is useful for overcoming marketing problems such as increased transaction costs and market uncertainty. Exploitation and opportunistic behavior of traders will be reduced if they join BUMDes or cooperatives (Sathapatyanon et al., 2018).. The existence of cooperatives will provide many benefits for farmers who have just provided transaction costs, increased bargaining power, higher prices, better access to financial resources, capacity building, and learning by sharing information (Promme et al., 2017; Poole \& Donovon, 2014)

In Indonesia, BUMDes can play a role ranging from upstream to downstream of all businesses, for example in the provision of capital, the provision of production facilities, product processing, marketing of products and developing other businesses in accordance with the potential and development of the village.

BUMDes also serves to bridge the interests and needs of the people with external parties such as banks to provide loans, with the government and the business community to raise funds, partnerships, training, and others. In other words, BUMDes is basically a consolidated and integrated effort to strengthen rural economic institutions. The important things that should be done by BUMDes as the power base of the rural economy are: a) to increase the capacity and ability of the community, b) to integrate economy products in rural areas in order to have a good bargaining position in the marketing network, $c$ ) to classify the public in its peer group in order to create economic scale, d) to increase the institutional capacity of the rural economy and rural institutions, e) to provide capital through micro-credit schemes, and f) to gain market information and establish communication with external parties. Thus, the rural economy will emerge toward independence gradually and systematically (Sathapatyanon et al., 2018).

The next step after BUMDes development is the establishment of business units in accordance with the need to sustain economic activity society efforts towards a more independent and sustainable. The established business units will strengthen the presence BUMDes in encouraging all rural economic productive activities. The required business units such as micro-credit units, provision of production facilities, marketing, and other units which are in accordance with the economic interests and development of rural community needs, government institutions and business communities can play a role as a business partner that can support economic activities of farmers.

Marketing scheme in the development of the economy can be explained as follows: 1) BUMDes as an economic institution belongs to the village through marketing units will be the main actor in the marketing of commodities produced by the society. The unit runs the marketing functions ranging from purchasing, collecting, and product marketing; 2) Farmer groups, farmers and people can sell and collect every commodity produced through BUMDes to be marketed; 3) To facilitate development and create economical business scale, BUMDes can make contracts with farmers, farmer groups, and other businesses communities. The contract can be used as assurance to maintain the stability and continuity of supply to the next marketing agency; 4) In marketing products, BUMDes can deliver directly to the local marketing companies and institutions established by the district to facilitate the marketing of all commodities produced by the society under the BUMDes; 5) Regional Marketing Agencies can market commodities to the public auction market, agribusiness center developed in some areas to serve not only regional trades but also exports.

\section{Conclusion}

Based on the research findings and discussion, then a number of conclusions related to the supply chain of rice in Malang: 1) The distribution pattern of unhulled rice/rice in Malang Regency consists of several groups of leading actors. They are traders (collectors), millers, wholesalers, Bulog Sub Division of Malang, wholes; 2) In general, the market structure of unhulled rice / rice in Malang is quite competitive. It is characterized by a number of market 
participants at the village, district or regency level. The distribution pattern of unhulled rice / rice has been formed long ago supported by adequate infrastructure, the distribution of unhulled rice / rice from the producers (farmers) to RMU, SubBulog as well as to wholesalers and retailers is quite smooth and does not encounter any major obstacles. 3) Source of rice supply in circulation in Malang Regency generally does not only come from Malang Regency, but also from various regencies in East Java and even from Central Java and West Nusa Tenggara which mainly occurs when the supply of rice in Malang is insufficient. On the other hand, Malang Regency also supplies rice to the East Java regions. 4) The roots of the problems faced in efforts to increase added value of the rice supply chain of rice is so varied with different levels of difficulty that requires serious treatments. Therefore, the efforts to increase the added value of the rice supply chain needs to involve all components which are divided into three series: production facilities assurance system, production process assurance system, and marketing process assurance system. 5) To strengthen the rice supply chain requires system development and enhancement. Making connections among upstream, downstream and support subsystem will make the existing system solid, so it will strengthen the supply chain as well as expand the scope of business actors such as product processing, financial institutions and marketing agencies.6) One of the economic institutions to support those activities is the village-owned enterprise (BUMDes). BUMDes also serves to bridge the interests and needs of the community with external parties such as banks, government and businesses, so gradually and systematically the strength of the rural economy will emerge toward independence.

Things that need to be done by the relevant institutions to maintain price stability and increase rice production include: 1) The Indonesian government should provide funds to buy all rice produced by farmers at a price that supports farmers in making a profit, then distribute it to the people at a price affordable to the people's purchasing power. 2) Improve the effectiveness of market operations conducted by Bulog, not to wait for the price to fall, but the market operation is done to prevent the price from falling through the mechanism of coordination with the Department of Industry and Trade, as well as the Food Security Agency (BKP) in food procurement which is in partnership with the cooperatives, Rice Milling Unit (RMU) and district level traders. The effectiveness of this program will be able to stabilize the rice price at a critical time that is harvest in the rainy season. 3) Empowering groups of farmers in rice production centers to strengthen their capital through small-scale RMU and the dryer ownership will be able to reduce the saturation of the unhulled rice market. Groups of farmers or farmers as producers no longer sell unhulled rice, but able to sell rice as well, therefore, rice added value will be enjoyed by members of their own group. Thus, the rice agribusiness in the level of farmer group can run well. 4) Farmers can take advantage of roving RMU, thus it will stimulate farmers to store unhulled rice for family consumption purposes. Farmers can mill the unhulled rice at any time with no extra transportation costs. This results the food security (rice) at the level of the farmers' family becomes stronger, by storing unhulled rice done by each farmer at a minimum amount of 0.5 to 1 ton MPD, this can reduce the supply of unhulled rice at harvest time. 5) The challenge for local BKP3 is to be able to create a map of rice production in the region works. The map can describe areas where the farmers' actual production is approaching the potential production of their land as well as areas where the actual production is still far from the land's potential, or in other words, where the yield gap is still wide. With the existence of this map, it will make it easier for the implementation of research and selecting the location. The priority of location assessment must be targeted to the areas that have a wide yield gap, in order to be able to narrow down the gap, so that the farmers' actual production can be close to or even equal the production potential of their land. Thus, the land resources will be used more optimally. 6) In order that the rice quality can be better absorbed by Bulog, it must also be accompanied with the revitalization of rice mills in the area. With the revitalization of the rice mill, then the level of fault rice can be diminished as low as possible, so that bad quality of rice due to bad RMU can be avoided. 7) The concept of OVOP (One Village One Product) and its control to centralize food production in each village or district should be done. Therefore, the diversity of food production can be larger and the potential of each region to be able to develop according to their products can be increased. In order to make it easier to do these suggestions, it requires a mapping or clustering based on the food situation and region in each village or district in Malang Regency. 8) In anticipation to the increase in consumption, research on the technology of cultivation and post-harvest of commodities which is predicted to be deficit needs to be done and developed in order that Malang Regency does not only rely on import. In addition, it is necessary to do institutional emendation and review in facing the estimation of rise on the consumption of particular commodities in Malang Regency. 9) Optimization of coordination with the relevant Stake Holders (Incorporated Companies, farmers, Department of Trade and Industry, Department of 
Agriculture and BKP3 Malang) should be done to avoid the markdown of unhulled rice price due to the harvest. In fact, the socialization about warehouse receipt system should be maximize, so people can keep their unhulled rice $/$ rice temporarily while waiting for prices to recover.

\section{References}

Ahumada, O., \& Villalobos, J. R. (2009). Application of planning models in the agri-food supply chain : A review. European Journal of Operational Research, 196(1), 1-20. https://doi.org/10.1016/j.ejor.2008.02.014

Aji, J. M. M. (2012). Rice supply chains in indonesia : how do they work ? Icam, (62), 473-488. Jember, Indonesia.

Anatan, L., \& Ellitan, L. (2008). Supply Chain Management: Teori dan Aplikasi. Bandung: Alfabeta.

Aramyan, L., Ondersteijn, C., Kooten, O. V. A. N., \& Lansink, A. O. (2006). Performance indicators in agri-food production chains. In Quantifying the agri-food supply chain (pp. 47-64).

Bala, B. K., Bhuiyan, M. G. K., Alam, M. M., Arshad, F. M., Sidique, S. F., \& Alias, E. F. (2016). Modelling of supply chain of rice in Bangladesh. International Journal of System Science: Operations \& Logistics, 2674(May). https://doi.org/10.1080/23302674.2016.1179813

Brown, J. G. (1994). Agroindustrial investment and operations. The World Bank.

Chopra, S., \& Meindl, P. (2004). Supply chain management: strategy, planning, and operation (Vol. 232).

Collins, R., Dunne, T., \& Keeffe, M. O. (2002). The "locus of value": a hallmark of chains that learn. Supply Chain Management: An International Journal, 7(5), 318-321. https://doi.org/10.1108/13598540210447764

Dinu, M. D. (2016). Supply chain performance within agri food sector. Economics of Agriculture, 63(3), 919-928.

Firdaus, M., Baga, L. M., \& Pratiwi, P. (2008). Swasembada beras dari masa ke masa : telaah efektivitas kebijakan dan perumusan strategi nasional (L. M. Baga \& P. Pratiwi, Eds.). Bogor: IPB Press.

Guritno, A. D., Kristanti, N. E., \& Tanuputri, M. R. (2018). Risk Mitigation on Supply Chain of Rice : Case Study at Demak and Sleman Districts. Agritech, 38(3), 375-380.

Harrison, A., \& Hoek, R. Van. (2008). Logistics Management and Strategy: Competing through the supplu chain (Third Edit). England: Prentice Hall.

Lambert, D. M., Cooper, M. C., \& Pagh, J. D. (1998). Supply Chain Management: Implementation Issues and Research Opportunities. The International Journal of Logistics Management, 9(2).

Lin, P., \& Wu, L. (2011). How supermarket chains in Taiwan select suppliers of fresh fruit and vegetables via direct purchasing. The Service Industries Journal, 31(8), 1237-1255. https://doi.org/10.1080/02642060903437568

Nee, A. Y. H. (2008). Supply chain model for rice in malaysia - basics and challenges. ECER Regional Conference, (January).

Obura, J., Ombok, B. O., \& Omugah, G. (2017). Analysis of Rice Supply Chain in Kenya. International Journal of Managerial Studies and Research, 5(8), 12-17.

Oliver, R. K., \& Webber, M. D. (1982). Supply-chain management: logistics catches up with strategy. Outlook, 5(1), 42-47.

Poole, N., \& Donovon, J. (2014). Building cooperative capacity : the specialty coffee sector in Nicaragua. Journal of Agribusiness in Developing and Emerging Economies, 4(2), 133-156. https://doi.org/10.1108/JADEE-01-20130002

Promme, P., Kuwornu, J. K. M., Jourdain, D., Shivakoti, G. P., \& Soni, P. (2017). Factors influencing rubber marketing by smallholder farmers in Thailand. Development in Practice, 27(6), 865-879. https://doi.org/10.1080/09614524.2017.1340930

Saragih, J. P. (2016). Kelembagaan Urusan Pangan dari Masa ke Masa dan Kebijakan Ketahanan Pangan. Jurnal Ekonomi \& Studi Pembangunan, 17(2), 168-192. https://doi.org/10.18196/jesp.17.2.3983

Sathapatyanon, J., Kuwornu, J. K., Shivakoti, G. P., Soni, P., Anal, A. K., \& Datta, A. (2018). The role of farmer organization and network in the rice supply chain in Thailand. Journal of Agribusiness in Developing and Emerging Economies. 
Sharma, V., Giri, S., \& Rai, S. S. (2013). Supply chain management of rice in india : a rice processing company's perspective. International Journal of Managing Value and Supply Chain, 4(1), 25-36. https://doi.org/10.5121/jmvsc.2013.4103

Shukla, M., \& Jharkharia, S. (2013). Agri-fresh produce supply chain management: a state-of-the-art literature review. International Journal of Operations \& Production Management, 33(2), 114-1158. https://doi.org/10.1108/01443571311295608

Simchi-Levi, D., Kaminsky, P., Simchi-Levi, E., \& Shankar, R. (2008). Designing and managing the supply chain: concepts, strategies and case studies. Tata McGraw-Hill Education.

Sudaryanto, T. (2013). Rice Development Policy in Indonesia. FFTC Agricultural Policy Platform, 1-3.

Timsina, K. P., Bastakoti, R. C., \& Shivakoti, G. P. (2016). Achieving strategic fit in onion seed supply chain. Journal of Agribusiness in Developing and Emerging Economies, 6(2), 127-149.

Van Der Vorst, J. G. A. J. (2006). Performance measurement in agri-food supply-chain networks. In Quantifying the agri-food supply chain (pp. 15-26).

Yan, M., Terheggen, A., \& Mithofer, D. (2017). Who and what set the price of walnut for small-scale farmers in Southwesst China? Journal of Agribusiness in Developing and Emerging Economies, 7(2), 135-152. 